\title{
The importance of preliminary evaluation in developing ambulance staff training curriculum for developing countries: A survey in Uzbekistan
}

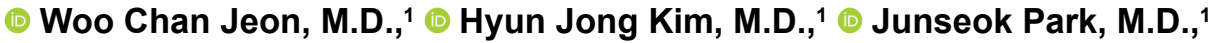 \\ ๑ Kyung Hwan Kim, M.D., ${ }^{1} \odot$ Dong Wun Shin, M.D., ${ }^{1} \odot$ Joon Min Park, M.D., ${ }^{1}$ \\ 다 Jung Eon Kim, M.D., ${ }^{1}$ ㄴ Ji Sook Lee, M.D., ${ }^{2} \odot$ Hoon Kim, M.D.
}

${ }^{1}$ Department of Emergency Medicine, Inje University, Ilsan Paik Hospital, Goyang-Korea

${ }^{2}$ Department of Emergency Medicine, Ajou University, School of Medicine, Suwon-Korea

\begin{abstract}
BACKGROUND: The Tashkent city, the capital of the republic of Uzbekistan, started joint project with Korean emergency physicians to improve the quality of their ambulance services in 2016. Ambulance service in Tashkent city has been facing challenges in processing a large number of calls, and low competency of their staff in providing advanced prehospital emergency care. To design an appropriate capacity building training program for ambulance staff, we analyzed the current ambulance service in Tashkent concerning resources and competency of the staff.
\end{abstract}

METHODS: In this study, ambulance staff participated in the constructed survey and pre-validated written test. Statistics and other information were provided by the Ministry of Health of Uzbekistan.

RESULTS: Ninety-eight ambulance staff were participated in this study, and more than half (53.1\%) of the participants were physicians. The average years of service in the ambulance were $8.71 \pm 6.9$ years. In the ambulance, drugs were stocked in enough quantity include injections for critical care, except large volume fluids for resuscitation. Only 19 to 52 percent of the ambulances were equipped with essential monitoring devices. Competency for the basic procedure was surveyed higher than $60 \%$, but critical care skills, such as defibrillation, were as low as $18 \%$. The written test resulted in only $41.1 \%$ correct answer rate, though it was higher than $60 \%$ in the validation test for Korean ambulance staff. Conventional prehospital knowledge and skillset deemed to be essential for ambulance staff were found to be marginal in the test.

CONCLUSION: The ambulance staff in Tashkent, Uzbekistan found to have insufficient medical knowledge and clinical decisionmaking abilities. Training program for ambulance staff in Tashkent should be developed on the basis of the findings in this study.

Keywords: Capacity building; emergency medical services; self-evaluation programs; Uzbekistan.

\section{INTRODUCTION}

In the $20^{\text {th }}$ century, public health policy of low and middle-income countries mainly emphasized maternal care and control of communicable diseases. ${ }^{[l]}$ However, the focus has shifted to non-communicable diseases, such as ischemic heart disease, stroke, and road injury, have become the major causes of death in low and middle-income countries. ${ }^{[2]}$ Hence, many reports have recommended developing and reinforcing the emergency medical services (EMS) in low middle-income countries. ${ }^{[3,4]}$ Given that the development and reinforcement of EMS require a considerable amount of human resources, and financial supports, foreign aid projects play an important role in meeting the needs through developing EMS algorithm and EMS staff training program in low middle-income countries. $^{[3]}$

Cite this article as: Jeon WC, Kim HJ, Park J, Kim KH, Shin DW, Park JM, et al. The importance of preliminary evaluation in developing ambulance staff training curriculum for developing countries: A survey in Uzbekistan. Ulus Travma Acil Cerrahi Derg 2020;26:9-14.

Address for correspondence: Hoon Kim, M.D.

2240 Daehwa-dong, Ilsan Seo-gu, Goyang-si, Gyeonggi-do, Korea 10380 Goyang-si - South Korea

Tel: +82-31-910-9782 E-mail: megali@hanmail.net

Ulus Travma Acil Cerrahi Derg 2020;26(I):9-14 DOI: 10.14744/tjtes.2019.79595 Submitted: 13.10.2018 Accepted: II.03.2019 Online: 27.12.2019

Copyright 2019 Turkish Association of Trauma and Emergency Surgery 
From January to April 2016, in cooperation with the Ministry of Health of Uzbekistan, the team of emergency physicians from Korea analyzed the status of the emergency medical system in Tashkent, the capital of Uzbekistan, and confirmed the feasibility of the EMS reinforcement project. The objective of this project is to contribute to the improvement of the emergency medical care system quality, enhancement of hospital operation efficiency, and the strengthening of the public medical system in Uzbekistan through practical and efficient capacity building program for pre-hospital emergency medical staff working in Tashkent. The project included the development and operation of the emergency medical personnel capacity building program.

In Tashkent, the ambulance staff is comprised of various healthcare workers, such as general physicians, feldshers, and nurses. The education system of the ambulance staff is as follows: general physicians should have completed three years of college or lyceum (such as vocational-technical school) and seven years of the medical school curriculum. The general physicians must also have passed the written and oral tests for a license. Feldshers, who are health care personnel that provide medical services limited to emergency treatment and ambulance service, provide primary, obstetric and surgical care in Uzbekistan. Training for feldshers includes up to four years of post-secondary education, including knowledge and skill for diagnosis and treatment. ${ }^{[5]}$ The curricula for nurses consist of three years of college or lyceum with an extension of two or three years for nursing education in medical high school. To become an ambulance staff, the general physician, feldsher and nurse should complete an additional one-year course of postgraduate education. ${ }^{[6]}$

In Tashkent, I 40 ambulances were identified as operational with 1,642 staff in 2016. The ambulance staff had two roles in Tashkent. First, when the patient's condition is deemed to be non-emergent, the ambulance staff act as a visiting primary physician and provide on-scene primary care without transportation to the hospital. Second, if the patient's condition is determined to be emergent, the ambulance staff is responsible for the transportation of the patient to the designated emergency facilities. Since ambulance service is free public service in Tashkent, many people use it when they need medical attention, even with minor symptoms. Frequently, available resources are diverted to primary medical care, raising concern for endangering emergent cases. Researchers have described the importance of enhancing the capacities of ambulance staff in implementing on-scene triage and proper management of the emergent patient. ${ }^{[6]}$ To this end, we performed the preliminary evaluation of emergency medical staff for developing a training program. This project aimed to help the development of EMS training program in low middle-income countries by introducing preliminary evaluation about the medical equipment in ambulances, medical knowledge in dealing with emergencies, and the clinical decision-making process of ambulance staff in Uzbekistan.

\section{MATERIALS AND METHODS}

In cooperation with the Ministry of Health of Uzbekistan, we collected data about the staff working at an ambulance station in Tashkent city as ambulance staff, dispatcher, or medical director. A survey was conducted to identify the personal data, emergency medical equipment and clinical experiences of the related personnel. A written test was formulated to evaluate medical knowledge and clinical decision-making skills (Appendix A). Both the survey sheet and written test were translated into the Russian language and distributed to the participants. This study was reviewed and approved by the Institutional Review Board of Inje University, Ilsan Paik Hospital. Informed consent was waived by the board.

The survey sheet contained demographics of participants, type of certification, durations of clinical experience, recent education opportunity and the role in the EMS to grasp the general characteristics of the participants. The medical equipment in the ambulance was also surveyed. First, the list of medical equipment in the ambulance was reviewed and categorized, and then, a questionnaire regarding the functionality of medical equipment in the ambulance was filled out. Items included intravenous medicines and fluids as well as medical device assisting emergency management and monitoring of the patients. The participants also asked to judge their own clinical performance related to competency, experience and confidence. The survey about clinical performance consisted of three contents. One is related to clinical performance assisting the airway and breathing of patients and the other two are clinical performance assisting circulation of patients and trauma management, such as cervical immobilization. Researchers developed the written test on the basis of education programs, such as Basic Life Support, Advanced Cardiac Life Support, Advanced Trauma Life Support and Neonatal Resuscitation Program. ${ }^{[7-10]}$ This test was first validated in more than 100 ambulance staff in Korea, who are certified EMT (Emergency Medical Technician), with an average score higher than 60 percent. The test consisted of 32 questions in total; airway and oxygen therapy (four questions), basic cardiopulmonary resuscitation (four questions), electrocardiogram (eight questions), advanced cardiopulmonary resuscitation (eight questions), prehospital trauma assessment and management (four questions) and neonatal resuscitation (four questions).

\section{RESULTS}

\section{General Characteristics of the Participants}

Ninety-eight emergency medical staff participated in this study. There were 73 male and 25 female participants. The average age was $34.68 \pm 8.71$ years old. The certification type of participants was 52 physicians (53.1\%), 42 feldshers (42.8\%), and three nurses (3.1\%). The average training hours they attended in recent two years was 171.4 hours. The composition of the clinical experience of participants was as follows. Ambulance boarding was $74 \%$, general hospital working was 15\%, outpa- 
Table I. General characteristics of the participants

\section{Frequency Years}

(\%)

\begin{tabular}{lcc}
\hline $\begin{array}{l}\text { Age } \\
\text { Sex }\end{array}$ & $34.68 \pm 8.7$ I (20-59) \\
$\quad$ Male & $25(25.5)$ & \\
$\quad$ Female & & \\
Medical certification & $52(53.1)$ & \\
$\quad$ General physician & $42(42.8)$ & \\
Feldsher & $3(3.1)$ & \\
Nurse & & \\
History of clinical & & \\
experiences & & \\
Location & $90(73.7)$ & $8.71 \pm 6.9(\mathrm{I}-32)$ \\
Ambulance & $18(14.8)$ & $8.39 \pm 7.03(\mathrm{I}-22)$ \\
General hospital & $\mathrm{II}(9.0)$ & $7.04 \pm 6.00(\mathrm{I}-20)$ \\
OPD/community hospital & $3(2.5)$ & $\mathrm{I} .67 \pm 0.94(\mathrm{I}-3)$ \\
\hline Dispatcher & &
\end{tabular}

OPD: Outpatient department.

tient or community hospital practice was $9 \%$, and dispatcher in EMS was $9 \%$. The average years of service in EMS were $8.71 \pm 6.9$ years for the ambulance, $8.39 \pm 7.03$ years for general hospital, $7.04 \pm 6.00$ years for outpatient or community hospital, and I.67 \pm 0.94 years for the dispatcher (Table I).

\section{Medical Equipment in the Ambulance}

The ambulances in Tashkent had various kinds of intravenous medicines, according to the survey. The list provided by the Uzbek side was compared with answers from participants to check the availability of each item. The cardiovascular drugs were epinephrine, atropine, amiodarone, lidocaine, digoxin, calcium gluconate; furosemide and antihypertensive (Table 2) More than $90 \%$ of the drugs were in stock in the ambulances, except for amiodarone (Table 2). Drugs other than the cardiovascular drugs included steroids, opioids, benzodiazepine and NSAIDs with some differences in each ambulance. Although the medical devices assisting emergency management and monitoring of the patients are essential, only 19 to 52 percent of the ambulances were equipped with the essential devices. There was a basic prehospital intravenous fluid, such as normal saline and dextrose, in about 60 percent of ambulances, but the volume of the intravenous fluid pack was as small as 100 to $200 \mathrm{~mL}$ (Table 2).

\section{Clinical Performances of the Participants}

The participants answered that the experience and confidence of skills related to basic airway management, such as oxygen supply, airway maneuvers and bag-mask ventilation, were over 60 percent (Fig. I). However, the experience and
Table 2. Medicines, fluids and medical equipment of ambulance in Tashkent, Uzbekistan

\begin{tabular}{lccc}
\hline $\begin{array}{l}\text { Intravenous } \\
\text { medicines }\end{array}$ & $\begin{array}{c}\text { Status } \\
(\%)\end{array}$ & $\begin{array}{c}\text { Medical } \\
\text { equipment }\end{array}$ & $\begin{array}{c}\text { Status } \\
\text { (\%) }\end{array}$ \\
\hline Epinephrine & 93.9 & Suction device & 50.0 \\
Atropine & 93.9 & Oxygen generator & 44.9 \\
Amiodarone & 5.1 & Laryngoscope & 19.4 \\
Lidocaine & 98.0 & Bag-mask & 58.2 \\
Digoxin & 5.96 & IV line set & 32.7 \\
Droperidol & 60.2 & Nasal cannula $\left(\mathrm{O}_{2}\right)$ & 7.1 \\
Diazepam & 16.3 & Face mask $\left(\mathrm{O}_{2}\right)$ & 24.5 \\
Calcium gluconate & 91.8 & Defibrillator & 60.2 \\
Nifedipine & 37.8 & Ventilator & 31.6 \\
Morphine & 96.9 & ECG monitor & 60.2 \\
Verapamil & 96.9 & Sat O monitor & 31.6 \\
Nitroglycerin & 85.7 & Splint & 77.6 \\
Heparin & 73.5 & Intravenous fluids & Status \\
Furosemide & 96.9 & Normal saline & 66.3 \\
Prednisolone & 96.9 & I0\% DW & 17.3 \\
Dextrose & 98.0 & $5 \%$ DW & 41.8 \\
MgSo4 & 96.9 & $50 \%$ DW & 59.2 \\
Drotaverine & 78.6 & Half saline & 15.3 \\
\hline & & &
\end{tabular}

confidence level related to techniques related to advanced airway and breathing support like endotracheal intubation, surgical airway and needle decompression were as low as 22 to 38 percent (Fig. I). In circulation support, more than 80 percent of the participants had the experience and confidence in measuring blood pressure and heart rate, establishing intravenous access, fluid infusion, and drug injection (Fig.

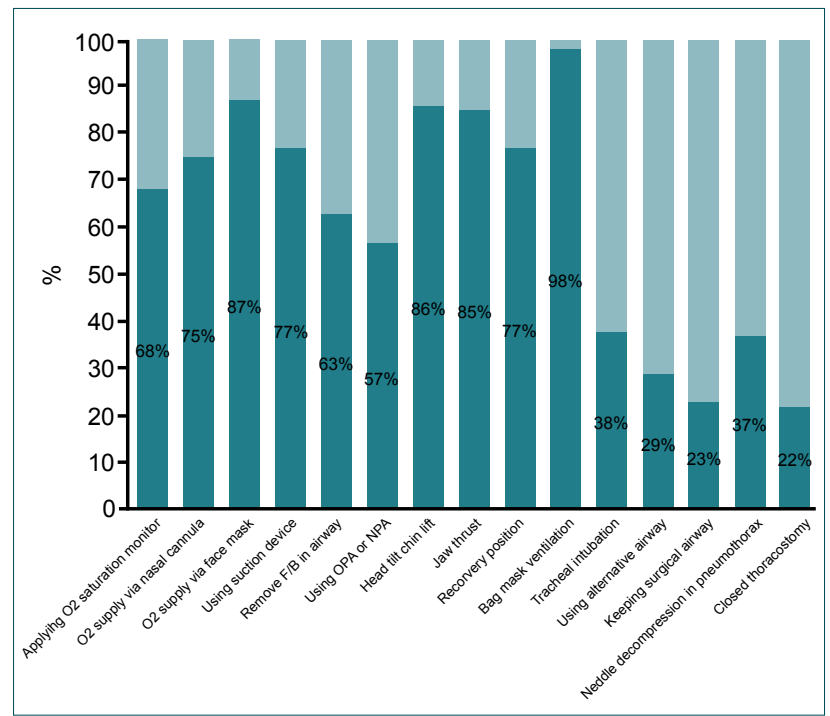

Figure 1. Clinical performance related to airway and breathing supports. F/B: Foreign Body; OPA: Oropharyngeal airway; NPA: Nasopharyngeal airway. 


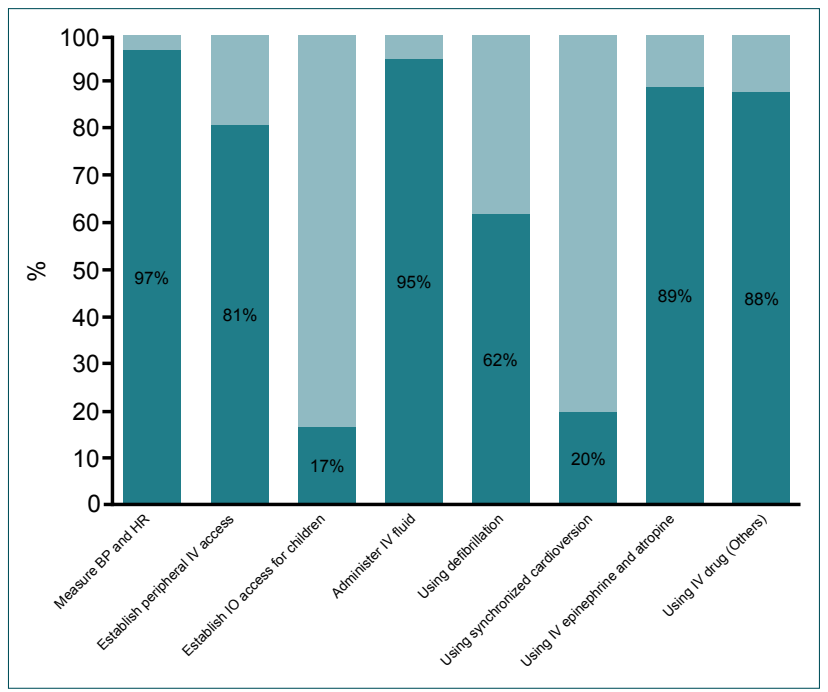

Figure 2. Clinical performances related to circulation support. BP: Blood pressure; HR: Heart rate; IO: Intraosseous; IV: Intravenous.

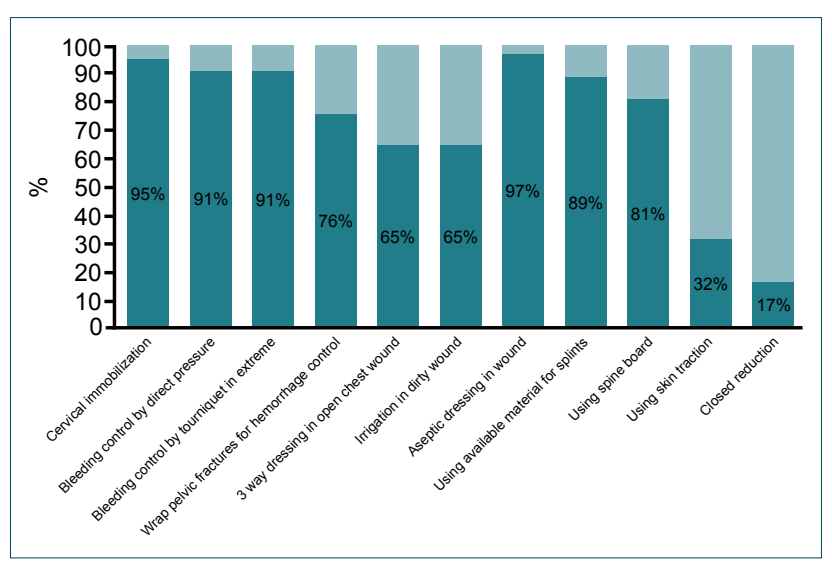

Figure 3. Clinical performance related to pre-hospital trauma care.

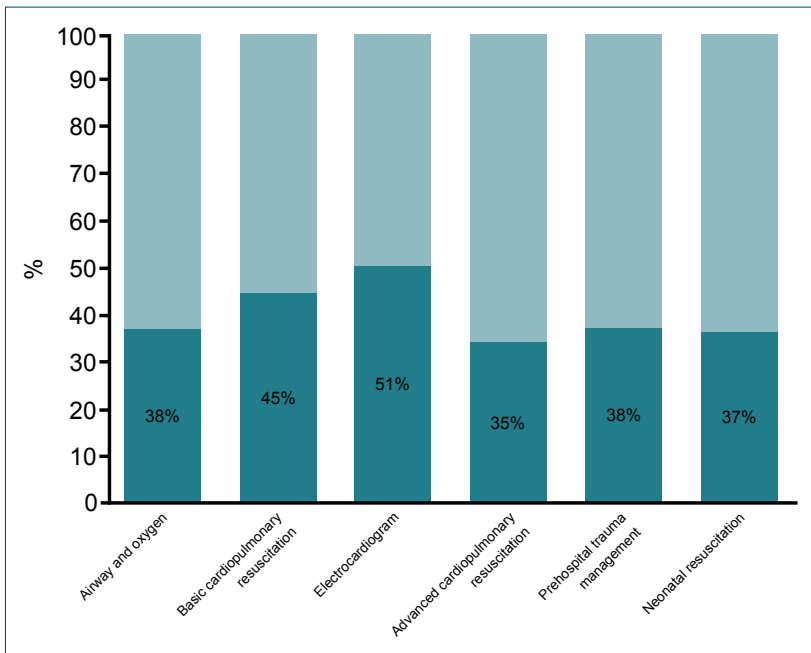

Figure 4. Correct answer rate of written test about medical knowledge and clinical decision.

2). However, only 18-20 percent of the participants had experience and confidence in using defibrillator and cardioversion critical in cardiopulmonary resuscitation. Experience and confidence in basic trauma management like bleeding control wound dressing and applying splints were relatively high at 60 to 97 percent (Fig. 3).

\section{Medical Knowledge and Clinical Decision}

The average rate of the correct answer in written test was only $41.1 \%$. In questions related to the airway and oxygen therapy section, advanced cardiopulmonary resuscitation section and prehospital trauma section, only 38,35 and 38 percent of participants selected correct answers, respectively. In the questions on basic cardiopulmonary resuscitation section, electrocardiogram section and neonatal resuscitation section, $45,5 \mathrm{I}$ and 46 percent of participants selected the correct answers, respectively (Fig. 4).

\section{DISCUSSION}

The ambulance in Tashkent, Uzbekistan had enough intravenous medication for emergency treatment. However, the medical device assisting emergency management and monitoring the condition of patients was insufficient, which may jeopardize the use of the available intravenous medicines in the field. Although there are basic intravenous fluids, such as normal saline and dextrose in the ambulance, the volume of fluid is only 100 to $200 \mathrm{~mL}$, which is not suitable for use in emergency situations. ${ }^{\left[{ }^{[1]}\right.}$ Therefore, developing the education course on the use of patient monitoring devices as well as on intravenous medicines provided in the ambulance was deemed essential. ${ }^{[12]}$ Also, national and institutional support should be placed to simplify the type of intravenous medicines that can be used in the ambulance, and to equip the ambulance with the patient monitoring system, and increase the volume of the intravenous fluid pack.

In most developed countries, including the United States, paramedics and emergency medical technicians play an important role in the emergency medical system. Although there are some differences in each country, most countries have a standardized education curriculum and certification system. Ambulance staff is healthcare professionals who respond to medical emergencies outside of a hospital and can not only transfer patients to the hospital but also perform invasive techniques, such as endotracheal intubation and chest compression on-site or during the transportation. ${ }^{[13,14]}$ According to the medical education curriculum in Uzbekistan, most ambulance staff in Tashkent (general physicians and feldshers) has already completed the education course about pre-hospital care, including critical care for severe patients. However, our written test revealed that knowledge, skills, and confidence in their clinical decision relevant to prehospital care were suboptimal.

In the assessment of medical knowledge and clinical decision of ambulance staff, in the airway and oxygen, advanced cardiopulmonary resuscitation, and prehospital trauma sections, above 60 percent of the participants chose the improper di- 
agnosis or wrong clinical decision. Hence, only half of the participants chose the proper diagnosis and clinical decision in the questions on basic cardiopulmonary resuscitation section, electrocardiogram section and neonatal resuscitation section. These results indicate that the ambulance staff in Tashkent is having difficulties in making appropriate judgments and clinical decisions in most emergency situations. Therefore, the researchers decided to develop the training program focused on basic principles of prehospital medical care. Program shall include airway management and breathing support, recognition of arrest, chest compression, interpretations of electrocardiogram and drug choice in cardiac arrhythmia.

Considering that Korean EMT, who are only degree holders, scored better than Uzbek ambulance staff with the same test, reasons for lower competency should be analyzed and measures should be developed to enhance their capacity. The ambulance staff in Tashkent also had insufficient clinical experience in advanced procedures. High confidence and experience in the basic techniques, such as oxygen supply, airway maneuvers, bag-mask ventilation, establishing intravenous access and drugs injection, the low confidence and experience of advanced technique, such as tracheal intubation, surgical airway, needle decompression, defibrillator and cardioversion, is probably due to the lack of practical training in the medical education curriculum and the lack of medical equipment in the field. Therefore, practice-based education program should be developed to increase the clinical experiences of ambulance staff in the field or the hospital. The development of practice-based program will require workshops or simulation session about the support of airway, breathing and circulation because ambulance staff had the lack of such clinical experiences. Moreover, scenario - based simulation education will be suitable to improve not only the clinical decisions but also clinical performance.

The present study aims to evaluate the medical knowledge and capability to make clinical decision and survey the clinical experiences and medical equipment in ambulances to develop training programs for ambulance staff in Tashkent, Uzbekistan. Considering that the role of ambulance staff is supposed to manage emergencies on scene and to rapidly transfer patients rather than be primary physicians, the program should include basic to advanced prehospital care. This study may be used as a reference to develop the training program of ambulance staff in not only Uzbekistan but also in the countries of the former Soviet Union and other developing countries with similar EMS system.

This study has some limitations. First, the researchers recruited the participants with the help of the Ministry of the Health of Uzbekistan. The participants could not represent the characteristics of all ambulance staff in Uzbekistan. Second, this research did not consider the differences in the education curriculum and the emergency medical system between Uzbekistan and Korea.

\section{Conclusion}

The ambulance staff in Tashkent, Uzbekistan found to have insufficient medical knowledge and the clinical decision-making abilities. The clinical performance of basic emergency management is good, but that of advanced emergency management seems to be marginal. The drug and medicines were enough, but medical equipment managing and monitoring the emergent patients was lack in ambulance of Tashkent. Training program for ambulance staff in Tashkent should be developed on the basis of the findings in this study.

Ethics Committee Approval: Approved by the local ethics committee.

Peer-review: Internally peer-reviewed.

Authorship Contributions: Concept: W.J., H.J.K. J.P., H.K.; Design: W.C.J., H.K., J.M.P., J.E.K., J.S.L.; Supervision: D.W.S., K.H.K., J.S.L.; Materials: W.J., H.J.K., J.P., H.K., J.E.K; Data: W.C.J., H.K., D.W.S., J.S.L.; Analysis: W.C.J., J.E.K., J.S.L., K.H.K., J.M.P.; Literature search: W.C.J., H.K., J.M.P.; Writing: W.C.J., H.K., J.S.L. Critical revision: K.H.K., D.W.S.

Conflict of Interest: None declared.

Financial Disclosure: The autors declared that this study has received no financial support.

\section{REFERENCES}

1. Macfarlane S, Racelis M, Muli-Muslime F. Public health in developing countries. Lancet 2000;356:841-6. [CrossRef]

2. Lozano R, Naghavi M, Foreman K, Lim S, Shibuya K, Aboyans V, et al. Global and regional mortality from 235 causes of death for 20 age groups in 1990 and 2010: a systematic analysis for the Global Burden of Disease Study 2010. Lancet 2012;380:2095-128. [CrossRef]

3. Kobusingye OC, Hyder AA, Bishai D, Hicks ER, Mock C, Joshipura M. Emergency medical systems in low- and middle-income countries: recommendations for action. Bull World Health Organ 2005;83:626-31.

4. Suryanto, Plummer V, Boyle M. EMS systems in lower-middle income countries: a literature review. Prehosp Disaster Med. 2017;32:64-70.

5. Sidel VW. Feldshers and "feldsherism" The role and training of the feldsher in the USSR. N Engl J Med 1968;278:987-92. [CrossRef]

6. Ahmedov M, Azimov R, Mutalova Z, Huseynov S, Tsoyi E, Rechel B. Uzbekistan: health system review. Health Syst Transit 2014;16:1-137.

7. Kleinman ME, Brennan EE, Goldberger ZD, Swor RA, Terry M, Bobrow BJ, et al. Part 5: adult basic life support and cardiopulmonary resuscitation quality: 2015 American Heart Association guidelines update for cardiopulmonary resuscitation and emergency cardiovascular care. Circulation 2015;132:S414-S35. [CrossRef]

8. Jayaraman S, Sethi D, Chinnock P, Wong R. Advanced trauma life support training for hospital staff. Cochrane Database Syst Rev 2014;CD004173.

9. Link MS, Berkow LC, Kudenchuk PJ, Halperin HR, Hess EP, Moitra VK, et al. Part 7: Adult Advanced Cardiovascular Life Support: 2015 American Heart Association Guidelines Update for Cardiopulmonary Resuscitation and Emergency Cardiovascular Care. Circulation 2015;132:S444-64. [CrossRef]

10. Wyckoff MH, Aziz K, Escobedo MB, Kapadia VS, Kattwinkel J, Perlman JM, et al. Part 13: neonatal resuscitation: 2015 American Heart Association guidelines update for cardiopulmonary resuscitation and emergency cardiovascular care. Circulation 2015;132:S543-S60.

11. Annane D, Siami S, Jaber S, Martin C, Elatrous S, Declère AD, et al. 
Effects of fluid resuscitation with colloids vs crystalloids on mortality in critically ill patients presenting with hypovolemic shock: the CRISTAL randomized trial. JAMA 2013;310:1809-17. [CrossRef]

12. Olasveengen TM, Sunde K, Brunborg C, Thowsen J, Steen PA, Wik L. Intravenous drug administration during out-of-hospital cardiac arrest: a randomized trial. JAMA 2009;302:2222-9. [CrossRef]
13. Wang HE. Paramedic endotracheal intubation. N C Med J 2007;68:272-5.

14. Gates S, Lall R, Quinn T, Deakin CD, Cooke MW, Horton J, et al. Prehospital randomised assessment of a mechanical compression device in out-of-hospital cardiac arrest (PARAMEDIC): a pragmatic, cluster randomised trial and economic evaluation. Health Technol Assess 2017;21:1-176. [CrossRef]

\section{DENEYSEL ÇALIŞMA - ÖZET}

\section{Gelişmekte olan ülkeler için ambulans personeli eğitim ders programlarının geliştirilmesinde ön değerlendirmenin önemi: Özbekistan'da bir anket çalışması \\ Dr. Woo Chan Jeon, ${ }^{1}$ Dr. Hyun Jong Kim, ${ }^{1}$ Dr. Junseok Park, ${ }^{1}$ Dr. Kyung Hwan Kim, ${ }^{1}$ Dr. Dong Wun Shin, ${ }^{1}$ Dr. Joon Min Park, ${ }^{1}$ Dr. Jung Eon Kim, ${ }^{1}$ Dr. Ji Sook Lee, ${ }^{2}$ Dr. Hoon Kim ${ }^{1}$}

${ }^{1}$ Inje Üniversitesi, Ilsan Paik Hastanesi, Acil Tıp Anabilim Dalı, Goyang-Kore

${ }^{2}$ Ajou Üniversitesi Tıp Fakültesi, Acil Tıp Anabilim Dalı, Suwon-Kore

AMAÇ: Özbekistan Cumhuriyeti'nin başkenti olan Taşkent şehri, 2016 yllında ambulans hizmetlerinin kalitesini yükseltmek için Koreli acil servis doktorlarıyla ortak bir proje başlatmıştır. Taşkent'teki ambulans hizmeti, çok sayıda çağrıyı işleme koymakta zorluklarla yüz yüze gelmekte olup hastane öncesi ileri acil hasta bakımı sağlamada kadroları yeterince yetkin değildir. Ambulans personeli için uygun kapasite geliştirme eğitim programı tasarlamak için, Taşkent'teki mevcut ambulans hizmetini kaynaklar ve personel yeterliliği açısından incelendi.

GEREÇ VE YÖNTEM: Ambulans personeli yapılandırılmış anket çalısmasına ve katılmış önceden geçerliliği onaylanmış yazılı teste katıldı. İstatistikler ve diğer bilgiler Özbekistan Sağlık Bakanlığı tarafından sağlandı.

BULGULAR: Çalışmaya 98 ambulans personeli katıldı, yarıdan fazlası (\%53.I) doktordu. Ambulansta ortalama hizmet süresi $8.7 I \pm 6.9$ yıldı. Ambulansta, resüsitasyon için büyük hacimli sıvilar haricinde kritik hasta tedavisi için enjektabl formları da içeren yeterli miktarda stoklanmış ilaç bulunmaktadır. Ambulansların sadece yüzde 19 ile 52'sinde gerekli monitörizasyon cihazları bulunuyordu. Temel prosedürlere ilişkin yeterlilik \%60'tan daha yüksek düzeyde olmasına rağmen, ancak defibrilasyon gibi kritik hasta bakım becerileri \%।8 kadar düşük oranda bulundı. Yazılı teste yalnızca \%4I.। oranında doğru yanıt verilmiş olmasına rağmen Kore ambulans personeli için validasyon testinde doğru yanıt oranı \%60'dan yüksekti. Ambulans personeli için gerekli görülen geleneksel hastane öncesi bilgi ve beceri setinin testte marjinal düzeyde olduğu tespit edildi.

TARTIŞMA: Özbekistan'ın Taşkent'teki ambulans personeli yetersiz tıbbi bilgi ve klinik karar verme yeteneklerine sahipti. Bu çalışmada elde edilen bulgular ışığında Taşkent'teki ambulans personeli için eğitim programı geliştirilmelidir.

Anahtar sözcükler: Acil sağılk hizmetleri; kapasite geliştirme; öz değerlendirme programları; Özbekistan.

Ulus Travma Acil Cerrahi Derg 2020;26(I):9-14 doi: 10.14744/tjtes.2019.79595 